\title{
Genomic findings in patients with clinical suspicion of $22 q 11.2$ deletion syndrome
}

\author{
Magdalena Koczkowska ${ }^{1}$ - Jolanta Wierzba ${ }^{2} \cdot$ Robert Śmigiel $^{3} \cdot$ Maria Sąsiadek $^{4}$. \\ Magdalena Cabała $^{3} \cdot$ Ryszard Ślężak $^{4} \cdot$ Mariola Iliszko $^{1} \cdot$ Iwona Kardaś $^{1}$ • \\ Janusz Limon ${ }^{1}$ • Beata S. Lipska-Ziętkiewicz ${ }^{1}$
}

Received: 25 April 2016 /Revised: 15 August 2016 / Accepted: 29 August 2016/Published online: 14 September 2016

(C) The Author(s) 2016. This article is published with open access at Springerlink.com

\begin{abstract}
Chromosome 22q11.2 deletion syndrome, one of the most common human genomic syndromes, has highly heterogeneous clinical presentation. Patients usually harbor a 1.5 to $3 \mathrm{Mb}$ hemizygous deletion at chromosome $22 \mathrm{q} 11.2$, resulting in pathognomic $T B X 1, C R K L$ and/or MAPK1 haploinsufficiency. However, there are some individuals with clinical features resembling the syndrome who are eventually diagnosed with genomic disorders affecting other chromosomal regions. The objective of this study was to evaluate the additive value of high-resolution array-CGH testing in the cohort of 41 patients with clinical features of 22q11.2 deletion syndrome and negative results of standard cytogenetic diagnostic testing (karyotype and FISH for 22q11.2 locus). Array-CGH analysis revealed no aberrations at chromosomes 22 or 10 allegedly related to the syndrome. Five (12.2\%) patients were found to have other genomic imbalances, namely 17q21.31 microdeletion syndrome (MIM\#610443), 1p36 deletion syndrome (MIM\#607872), NF1 microduplication
\end{abstract}

Communicated by: Michal Witt

Electronic supplementary material The online version of this article (doi:10.1007/s13353-016-0366-1) contains supplementary material, which is available to authorized users.

Beata S. Lipska-Ziętkiewicz

b.lipska@gumed.edu.pl

1 Department of Biology and Genetics, Medical University of Gdansk, 1 Debinki Street, 80-211 Gdansk, Poland

2 General Nursery, Medical University of Gdansk, 7 Debinki Street, 80-211 Gdansk, Poland

3 Department of Social Pediatrics, Wroclaw Medical University, 5 Bartla Street, 51-618 Wroclaw, Poland

4 Department of Genetics, Wroclaw Medical University, 1 Marcinkowskiego Street, 50-368 Wroclaw, Poland syndrome (MIM\#613675), chromosome 6pter-p24 deletion syndrome (MIM\#612582) and a novel interstitial deletion at $3 \mathrm{q} 26.31$ of $0.65 \mathrm{Mb}$ encompassing a dosage-dependent gene NAALADL2. Our study demonstrates that the implementation of array-CGH into the panel of classic diagnostic procedures adds significantly to their efficacy. It allows for detection of constitutional genomic imbalances in $12 \%$ of subjects with negative result of karyotype and FISH targeted for 22q11.2 region. Moreover, if used as first-tier genetic test, the method would provide immediate diagnosis in $\sim 40 \%$ phenotypic 22q11.2 deletion subjects.

Keywords 22q11.2 deletion syndrome - Array comparative genomic hybridization $\cdot 17 \mathrm{q} 21.31$ microdeletion syndrome $\cdot$ NF1 microduplication syndrome $\cdot$ chromosome $6 \mathrm{p} 25.3 \mathrm{p} 25.2$ deletion $\cdot N A A L A D L 2$

\section{Introduction}

Chromosomal rearrangements of 22q11.2 are implicated in several genomic disorders, microdeletion $22 \mathrm{q} 11.2$ being the most common recurrent syndrome with a prevalence of $\sim 1: 4000-1: 6000$ live births (Grati et al. 2015). The phenotype of patients with the deletion at 22q11.2 chromosome encompasses a number of clinical entities, including DiGeorge syndrome (DGS; MIM\#188400) and velocardiofacial syndrome (VCFS; MIM\#192430). The cardinal features comprise conotruncal heart defects, characteristic dysmorphic facies (unusually shaped ears, long nose with broad bridge, micrognathia and upslanting, short palpebral fissures) and velophryngeal insufficiency or cleft palate. Individuals with the more severe phenotype present T-cell immunodeficiency and persistent hypocalcaemia (Tobias et al. 1999; Bassett et al. 2011). Moreover, the presence of some features is determined 
by the age of individual, for instance psychiatric disorders are more commonly observed in adults (Schneider et al. 2014).

In $90 \%$ of patients with the 22q11.2 deletion, a common $\sim 3 \mathrm{Mb}$ deletion has been found, whereas $7 \%$ of cases share a smaller, nested $\sim 1.5 \mathrm{Mb}$ recurrent deletion. Among the remaining individuals atypical deletions or chromosomal translocations involving 22q11.2 have been reported (Schwinger et al. 2010). So far, haploinsufficiency of three genes (TBX1, $C R K L$ and $M A P K 1$ ) on $22 \mathrm{q} 11.2$ has been reported strongly associated with the syndrome (Schwinger et al. 2010; Breckpot et al. 2012; Rump et al. 2014; Racedo et al. 2015).

Due to the wide variability in the clinical presentation, the diagnosis based on phenotype evaluation is challenging. Even though the state-of-art diagnostic procedure for patients with the clinical suspicion of the $22 \mathrm{q} 11.2$ deletion syndrome is the targeted FISH testing, at present patients are usually diagnosed by indirect whole-genome studies, array-CGH being the case in point. Indeed, array-CGH has been recommended as the first-tier diagnostic test for patients with multiple congenital anomalies, developmental delay/intellectual disability and/or autism spectrum disorders; the indications fulfilled also with respect to 22q11.2 deletion syndrome (Henderson et al. 2014).

The aim of the current study was to estimate the efficacy of implementation of the array-CGH screening into the panel of classic diagnostic procedures in subjects resembling the 22q11.2 deletion phenotype. Accordingly, we have applied array-CGH technique to evaluate the incidence and to characterize genomic disorders in the group of patients with clinical features of 22q11.2 deletion syndrome and a normal karyotype and negative result of FISH for 22q11.2 locus.

\section{Clinical report}

\section{Enrollment procedure}

Patients from two clinical genetics outpatient clinics (at Gdansk and Wroclaw Medical Universities) were suspected of 22q11.2 deletion syndrome in view of the Tobias criteria (see below) (Tobias et al. 1999). In the years 2004-2014 the confirmation rate of the syndrome established through FISH studies performed using the commercially available D22S75/ N25 probe (Cytocell) was $15.8 \%$. In addition, five patients $(11.8 \%)$ were diagnosed with a chromosomal aberration in view of matched karyotype studies. The findings included two cases of a familial translocation $(4 ; 11)$; one case of an unbalanced $(\mathrm{X} ; 6)$ translocation, one case of an unbalanced $(14 ; 18)$ translocation and one case of a large interstitial deletion at chromosome $6 \mathrm{q}$. The remaining patients with the phenotype of $22 \mathrm{q} 11.2$ deletion syndrome and with normal results of the standard diagnostic testing (karyotype and targeted FISH) were contacted retrospectively and after obtaining informed consent eventually enrolled in the study.

\section{Cohort description}

The patients were evaluated by two clinical geneticists in view of the Tobias criteria (Tobias et al. 1999). Detailed clinical description of the patients is presented in Supplementary data 1. In brief, 20 (49\%) and $21(51 \%)$ out of 41 patients met one of the A criteria and at least two of the B criteria, respectively. None of the individuals were diagnosed based on the $\mathrm{C}$ criteria. Cardiac defects were detected in $90 \%$ of patients $(n=37)$, including a conotruncal anomaly and Fallot's tetralogy in $51 \%(19 / 37)$ and $16 \%(6 / 37)$, respectively. Characteristic facial features associated with $22 \mathrm{q} 11.2$ deletion syndrome were described in 33 patients $(80 \%)$; the most frequent being micro(retro)gnathia (58\%), unusually shaped ears $(55 \%)$, long nose with broad bridge (52\%) and short palpebral fissures $(30 \%)$. Learning difficulties and/or developmental delay were reported in 24 individuals (59\%), whereas $17 \%$ and $5 \%$ of cases were diagnosed with cleft palate and velopharyngeal insufficiency, respectively. Moreover, a total of 16 patients (39\%) had swallowing difficulties. Other anomalies, such as short stature and renal abnormalities were found in $17 \%$ and $15 \%$ of patients, respectively. Only $5 \%(2 / 38)$ of patients had primary immunodeficiency while none presented with persistent hypocalcaemia.

\section{Methods}

Array-CGH was performed at resolution of $25 \mathrm{~kb}$ using Human CGH 3x720K Whole-Genome Tilling Array (Roche, Basel, Switzerland) following the instructions provided by manufacturer with modifications as previously described (Ronowicz et al. 2012). All identified genomic imbalances were verified in the general access databases of genomic variants (DGV, ISCA and Decipher; last accessed December 2015). In selected cases, the de novo/familial origin of the aberration was established using qPCR technique. The study was approved by the Research Ethics Committee of Medical University of Gdansk.

\section{Results}

No genomic aberrations at chromosomes 10 and 22 purportedly related to the syndrome were detected. Five patients $(12.2 \%)$ were found to have a submicroscopic genomic imbalances of the mean size of $1.5 \mathrm{Mb}$ (Table 1). Patient 29 harbored a 2.1 interstitial deletion of chromosome $1 \mathrm{p} 36.33 \mathrm{p} 36.32$, encompassing a total number of 82 genes, including the GABRD and SKI genes, the region typical for the $1 \mathrm{p} 36$ deletion syndrome (MIM\#607872). In the individual 22 array-CGH analysis revealed a $2.7 \mathrm{Mb}$ terminal deletion of 


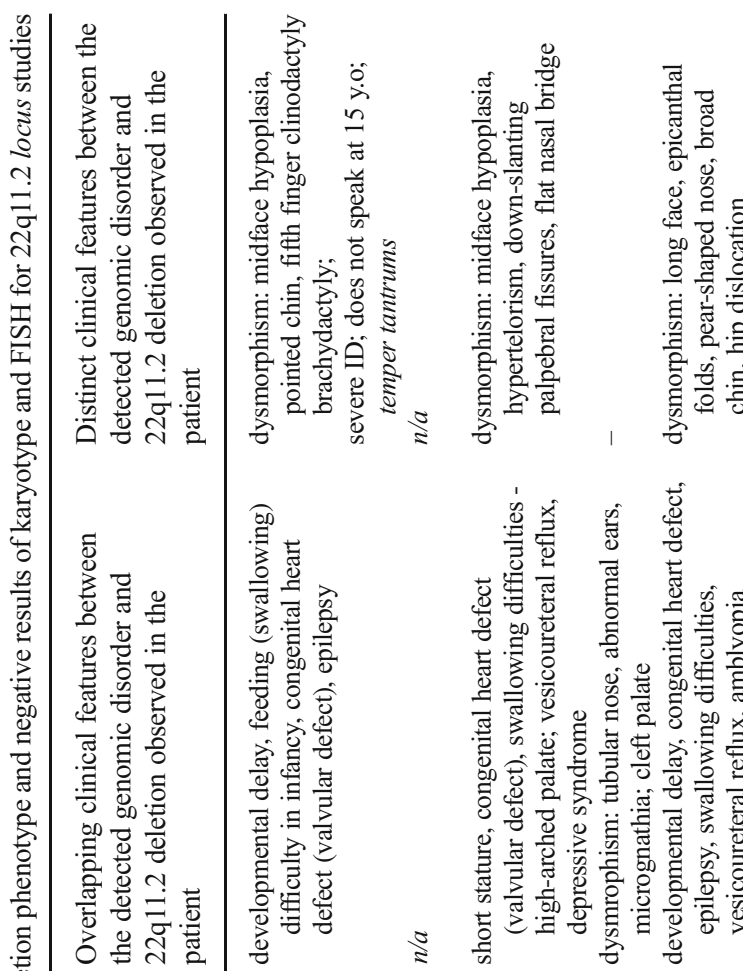

chromosome $6 \mathrm{p} 25.3 \mathrm{p} 25.2$, the minimal region of chromosome 6pter-p24 deletion syndrome (MIM\#612582), covering a total number of 18 genes, among which $\mathrm{FOXC1}$ is proposed as the candidate gene correlating with the reported phenotype. Also, two individuals had interstitial aberrations at chromosome 17. Patient 15 presented with an $1.5 \mathrm{Mb} \mathrm{du}-$ plication at $17 \mathrm{q} 11.2$, whereas a small deletion of $0.5 \mathrm{Mb}$ at $17 \mathrm{q} 21.31$ was found in patient 18 . The findings correspond with clinical diagnosis of NF1 microduplication syndrome (MIM\#613675) and Koolen-de Vries syndrome (MIM\#610443) respectively. A comparison of overlapping and distinct clinical features between the detected genomic disorders and the phenotype associated with 22q11.2 deletion is presented in Table 1.

Finally, a unique loss at chromosome $3 \mathrm{q} 26.31$ of $650 \mathrm{~kb}$ encompassing the entire NAALADL2 gene sequence, was identified in patient 41. qPCR analysis revealed the same deletion in two siblings of the patient (a sister with bilateral cleft lip and palate and a brother with congenital heart defect) and their apparently unaffected mother (for details see Supplementary data 2).

\section{Discussion}

Nowadays, the gold standard diagnostic procedure for 22q11.2 deletion syndrome is by conventional cytogenetic technique and targeted FISH analysis (Schwinger et al. 2010). Several studies have demonstrated that according to this approach the detection rate varies considerably (4-96\%) (Yagi et al. 2003; Smigiel et al. 2007; Brunet et al. 2009; Fernandez et al. 2008; Wozniak et al. 2010). However, a more practical approach is to perform a whole-genome analysis, as it not only allows one to identify the syndrome but at the same time may detect any other genomic syndrome presenting overlapping clinical features. To the best of our knowledge, our work is the first attempt to evaluate application of aCGH technique in the cohort of patients presenting phenotype resembling the $22 \mathrm{q} 11.2$ deletion syndrome.

To date, over 180 clinical features have been associated with the 22q11.2 deletion syndrome. Clinical diagnosis of 22q11.2 deletion syndrome remains a challenging task, because no single pathognomonic finding exists for the syndrome. Even though it has been postulated that the two major striking phenotypic features are: immunodeficiency and hypocalcaemia (Bassett et al. 2011), that was not shown in the large series of patients. Similar to the current series, in the recent report of almost 750 cases diagnosed in France over last 18 years the most frequent reasons for referral of postnatally diagnosed cases were a congenital heart defect (49\%), facial dysmorphism (50\%) and developmental delay (41\%). Hypocalceamia was present in $15 \%$ only, while immunodeficiency was not among referral causes; instead recurrent 
infections were reported in $8 \%$ and thymus agenesis in $7 \%$. Actually, $25 \%$ of the patients were referred because of a single feature; of these, half had a congenital heart defect only (Poirsier et al. 2015).

In the last ten years, the clinical diagnosis of the syndrome has been confirmed by FISH in $16 \%$ of the patients referred to our Outpatient Genetic Clinics (Fig. 1). Concurrent conventional cytogenetic analysis allowed us to identify genomic imbalances as the underlying cause of the observed phenotype in additional $12 \%$ of cases.

In this study, 41 patients with clinical signs of $22 \mathrm{q} 11.2 \mathrm{de}-$ letion syndrome and with negative standard diagnostic analysis were further evaluated using array-CGH. Five individuals (12.2\%) were diagnosed to harbor pathogenic genomic imbalances, including four known recurrent genomic disorders (Table 1). Our findings add on to the clinical spectrum of these syndromes and show that their clinical manifestation might mimic the presentation of the $22 \mathrm{q} 11.2$ deletion syndrome. Nonetheless, these patients lacked cardinal clinical signs, such as conotruncal heart defects or family history of 22q11.2 deletion syndrome; also their dysmorphic features were distinct from the 22q11.2 deletion phenotype in three of four individuals. Based on the results of array analysis reverse phenotyping was performed revealing incomplete phenotype in all of them (Table 1). The patient (\#22) with a $2.7 \mathrm{Mb}$ deletion at chromosome $6 \mathrm{p} 25$ did not present anterior eye chamber abnormalities (including Axenfeld-Rieger syndrome type 3 in particular) that are considered pathognomonic for the syndrome. Also, the boy (\#15) with a 1.5 duplication at 17q11.2 encompassing NF1 gene did not present developmental delay or seizures allegedly

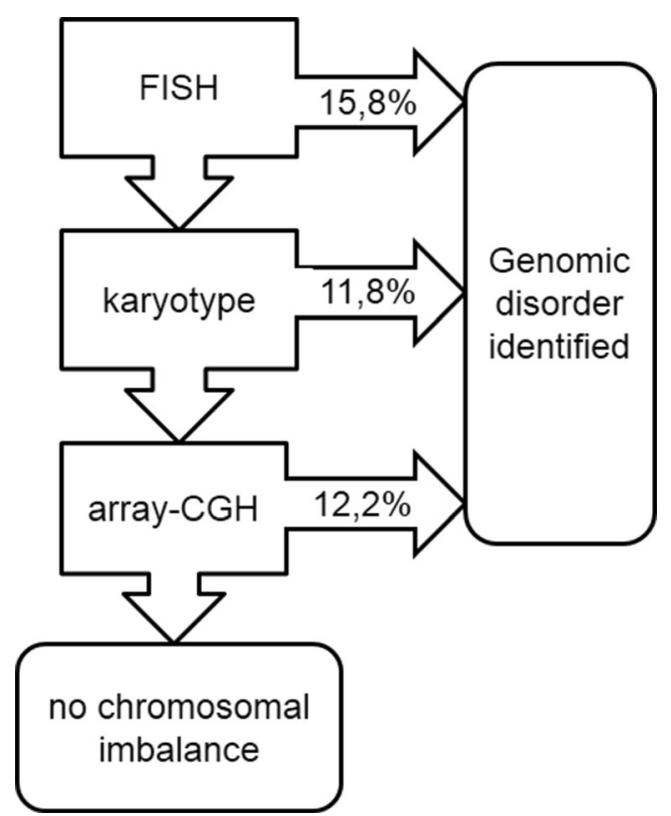

Fig. 1 The flow-chart showing subsequent detection rates of genomic disorders in patients with the clinical features of 22q11.2 deletion syndrome using various testing approaches (targeted FISH followed by conventional karyotyping, followed by array-CGH) reported in patients with such duplication. The girl (\#18) with a $0.5 \mathrm{Mb}$ deletion at $17 \mathrm{q} 21.31$ presented mild dysmorphic features and lacked blepharophimosis, ptosis, or abnormal hair pigmentation and texture usually observed in children with Koolen-de Vries syndrome. The girl (\#29) with a $2.1 \mathrm{Mb}$ deletion at chromosome 1p36 did not have structural abnormalities of the brain, vision or hearing impairment or other malformations usually present in children with the syndrome.

In addition to known recurrent syndromes, we identified a unique deletion at $3 \mathrm{q} 26.31$ of $0.65 \mathrm{Mb}$ size. The deletion encompasses only one dosage-dependent gene, NAALADL2 (MIM*608806), that is thought to be associated with the congenital defects, dysmorphic features and/or development delay (Millson et al. 2012). Family study (Supplementary data 2) revealed the variant to be present in two affected siblings of the patient and an apparently healthy mother indicating reduced penetrance and variable expressivity.

In the current study no submicroscopic chromosomal rearrangements at chromosome 22 or 10 allegedly related to the syndrome were identified. The losses at DGS2 locus located at $10 \mathrm{p} 13 \mathrm{p} 14$ chromosome have an estimated frequency of one in 200,000 live births (Daw et al. 1996; Lindstrand et al. 2010). The DGS2 clinical presentation is thought to be more severe than the regular 22q11.2 deletion syndrome with severe mental retardation in addition to immune deficiency and heart defects. Due to its rarity, and in line with the fact, that only a small fraction of the subjects studied in the current work presented with such a severe phenotype, our study might have disregarded such cases. Otherwise, our results are in line with the study of Bartsch et al. (1999), suggesting no evidence for genomic deletions at putative DGS2 locus on 10p in phenotypic $22 \mathrm{q} 11.2$ deletion patients.

The recommended optimal resolution for array-CGH used in routine diagnostics, that does not increase greatly the number of uncertain significance variants, is $200 \mathrm{~kb}$ (Vermeesch et al. 2012). In the current study we have used high-resolution array-CGH at $25 \mathrm{~kb}$ which did not improve diagnostic yield. It only increased the background noise related to the detected small CNVs of unknown significance (on average 2 per sample), eventually proven to be insignificant to the reported phenotype. Plausibly, the high resolution could be useful in detecting small aberrations, affecting the locus of $T B X 1$ gene in particular as previously reported by Chen et al. (2014), but no atypical small aberration at 22q11.2 locus was observed in the current series of patients.

Taking into account the high variability of phenotype in patients with the clinical suspicion of $22 \mathrm{q} 11.2$ deletion syndrome, we recommended to use array-CGH as the first-line genetic test, in place of conventional cytogenetic procedures and targeted FISH. Array-CGH has proven to increase the resolution and provide higher diagnostic yield than classical karyotyping which improves diagnostic capability (Miller et al. 2010; Kaminsky et al. 2013). In the presented study, if 
array-CGH had been used as the first-tier clinical diagnostic test it could have confirmed the diagnosis of a genomic disorder in $\sim 40 \%$ of individuals with clinical manifestation of the 22q11.2 deletion syndrome (Fig. 1). The resolution of the technique without any doubt could detect the imbalances present in the patients diagnosed at previous stages of diagnostic procedures (i.e. by FISH or conventional karyotyping). ArrayCGH appears not only as less time-consuming but also as the cost-effective technique. In the remaining $60 \%$ of patients, the screening for detection of unknown gene mutations by wholeexome sequencing (WES) should be considered. In line with the recommendations of the American College of Medical Genetics and Genomics (2012) and the European Society of Human Genetics (2013) WES analysis should be considered in the clinical evaluation of individuals with suspected genetic disorders only under certain circumstances. Interpretation of an enormous amount of raw data and the risk of identification of incidental (secondary) findings are the main limiting factors (ACMG 2012; van El et al. 2013).

In conclusion, our study confirms that array-CGH screening of individuals with clinical suspicion of 22q11.2 and the negative result of standard genetic testing increases the capacity to detect submicroscopic chromosomal aberrations and therefore allows one to make the proper diagnosis in a significant fraction of patients. Accordingly, we recommend arrayCGH testing as the first choice test in this particular clinical setting.

Acknowledgments We thank the patients and their families for participating in this study.

\section{Compliance with ethical standard}

Conflict of interest The authors declare that they have no conflict of interest.

Funding This work has been financed by the Polish National Science Centre grant 2011/01/D/NZ2/01600.

All procedures performed in studies involving human participants were in accordance with the ethical standards of the Medical University of Gdansk research committee and with the 1964 Helsinki declaration and its later amendments. Written informed consent was obtained from the relevant guardians of the children and from patients themselves, whenever eligible. The study was approved by the Ethical Committee of the Medical University of Gdansk, Poland.

\section{Web resources Database of Genomic Variants - http://dgv.tcag. ca/dgv/app/home \\ DECIPHER database - https://decipher.sanger.ac.uk/ \\ ISCA database - http://dbsearch.clinicalgenome.org/search/}

Open Access This article is distributed under the terms of the Creative Commons Attribution 4.0 International License (http:// creativecommons.org/licenses/by/4.0/), which permits unrestricted use, distribution, and reproduction in any medium, provided you give appropriate credit to the original author(s) and the source, provide a link to the Creative Commons license, and indicate if changes were made.

\section{References}

ACMG Board of Directors (2012) Points to consider in the clinical application of genomic sequencing. Genet Med 14:759-761. doi:10.1030/gim.2012.74

Bartsch O, Wagner A, Hinkel GK, Lichtner P, Murken J, Schuffenhauer S (1999) No evidence for chromosomal microdeletions at the second DiGeorge syndrome locus on 10p near D10S585 (Letter). Am J Med Genet 83:425-426

Bassett AS, McDonald-McGinn DM, Devriendt K, Digilio MC, Goldenberg P, Habel A, Marino B, Oskarsdottir S, Philip N, Sullivan K, Swillen A, Vortsman J, the International 22q11.2 Deletion Syndrome Consortium (2011) Practical guidelines for managing patients with 22q11.2 deletion syndrome. J Pediatr 159: 332.e1-339.e1. doi:10.1016/j.jpeds.2011.02.039

Breckpot J, Thienpont B, Bauters M, Tranchevent LC, Gewilig M, Allegaert K, Vermeesch JR, Moreau Y, Devriendt K (2012) Congenital heart defects in a novel recurrent 22q11.2 deletion harboring the genes CRKL and MAPK1. Am J Med Genet A 158 A: 574-580. doi:10.1002/ajmg.a.35217

Brunet A, Armengol L, Heine D, Rosell J, García-Aragonés M, Gabau E, Estivill X, Guitart M (2009) BAC array CGH in patients with velocardiofacial syndrome-like features reveals genomic aberrations on chromosome region 1q21.1. BMC Med Genet 10:144. doi:10.1186/1471-2350-10-144

Chen M, Yang YS, Shih JC, Lin WH, Lee DJ, Lin YS, Chou CH, Cameron AD, Ginsberg NA, Chen CA, Lee ML, Ma GC (2014) Microdeletions/duplications involving TBX1 gene in fetuses with conotruncal heart defects which are negative for 22q11.2 deletion on fluorescence in-situ hybridization. Ultrasound Obstet Gynecol 43: 396-403. doi:10.1002/uog. 12550

Daw SCM, Taylor C, Kraman M, Call K, Mao J, Schuffenhauer S, Meitinger T, Lipson T, Goodship J, Scambler P (1996) A common region of $10 \mathrm{p}$ deleted in DiGeorge and velocardiofacial syndromes. Nat Genet 13:458-461

Fernandez L, Lapunzina P, Pajares IL, Palomares M, Martinez I, Fernandez B, Quero J, Garcia-Guereta L, Garcia-Alix A, Burgueros M, Galan-Gomez E, Carbonell-Perez JM, PerezGranero A, Torres-Juan L, Heine-Suner D, Rosell J, Delicado A (2008) Unrelated chromosomal anomalies found in patients with suspected 22q11.2 deletion. Am J Med Genet A 146:1134-1141. doi:10.1002/ajmg.a.32256

Grati FR, Molina Gomes D, Ferreira, Jose Carlos Pinto B, Dupont C, Alesi V, Gouas L, Horelli-Kuitinen N, Choy KW, Garcia-Herrero S, Gonzalez de la Vega A, Piotrowski K, Genesio R, Queipo G, Malvestitil B, Herve B, Benzacken B, Novelli A, Vago P, Piippo K, Leung TY, Maggil F, Quibel T, Tabet AC, Simonil G, Vialard F (2015) Prevalence of recurrent pathogenic microdeletions and microduplications in over 9500 pregnancies. Prenat Diagn 35:801809. doi:10.1002/pd.4613

Henderson LB, Applegate CD, Wohler E, Sheridan MB, Hoover-Fong J, Batista D (2014) The impact of chromosomal microarray on clinical management: a retrospective analysis. Genet Med 16:1-8. doi:10.1038/gim.2014.18

Kaminsky EB, Kaul V, Paschall J, Church DM, Bunke B, Kunig D, Moreno-de-luca D, Mulle JG, Warren ST, Richard G, Compton JG, Fuller AE, Gliem TJ, Huang S, Collinson MN, Beal SJ, Ackley T, Pickering DL, Golden DM, Aston E, Whitby H, Shetty S, Rossi MR, Rudd MK, South ST, Brothman AR, Sanger WG, Iyer RK, Crolla JA, Thorland EC, Aradhya S, Ledbetter DH, Martin CL (2013) An evidence-based approach to establish the functional and clinical significance of copy number variants in intellectual and developmental disabilities. Disabilities 13:777-784. doi:10.1097/GIM.0b013e31822c79f9.An 
Lindstrand A, Malmgren H, Verri A, Benetti E, Eriksson M, Nordgren A, Anderlid BM, Golovleva I, Schoumans J, Blennow E (2010) Molecular and clinical characterization of patients with overlapping $10 \mathrm{p}$ deletions. Am J Med Genet A 152:1233-1243. doi:10.1002/ajmg.a.33366

Miller DT, Adam MP, Aradhya S, Biesecker LG, Brothman AR, Carter NP, Church DM, Crolla JA, Eichler EE, Epstein CJ, Faucett WA, Feuk L, Friedman JM, Hamosh A, Jackson L, Kaminsky EB, Kok K, Krantz ID, Kuhn RM, Lee C, Ostell JM, Rosenberg C, Scherer SW, Spinner NB, Stavropoulos DJ, Tepperberg JH, Thorland EC, Vermeesch JR, Waggoner DJ, Watson MS, Martin CL, Ledbetter DH (2010) Consensus statement: chromosomal microarray is a first-tier clinical diagnostic test for individuals with developmental disabilities or congenital anomalies. Am J Hum Genet 86:749-764. doi:10.1016/j.ajhg.2010.04.006

Millson A, Lagrave D, Willis MJH, Rowe LR, Lyon E, South ST (2012) Chromosomal loss of 3q26.3-3q26.32, involving a partial neuroligin 1 deletion, identified by genomic microarray in a child with microcephaly, seizure disorder, and severe intellectual disability. Am J Med Genet A 158 A:159-165. doi:10.1002/ajmg.a.34349

Poirsier C, Besseau-Ayasse J, Schluth-Bolard C, Toutain J, Missirian C, Le Caignec C, Bazin A, de Blois MC, Kuentz P, Catty M, Choiset A, Plessis G, Basinko A, Letard P, Flori E, Jimenez M, Valduga M, Landais E, Lallaoui H, Cartault F, Lespinasse J, Martin-Coignard D, Callier P, Pebrel-Richard C, Portnoi MF, Busa T, Receveur A, Amblard F, Yardin C, Harbuz R, Prieur F, Le Meur N, Pipiras E, Kleinfinger P, Vialard F, Doco-Fenzy M (2015) Eur J Hum Genet. doi:10.1038/ejhg.2015.219

Racedo SE, McDonald-Mcginn DM, Chung JH, Goldmuntz E, Zackai E, Emanuel BS, Zhou B, Funke B, Morrow BE (2015) Mouse and human CRKL is dosage sensitive for cardiac outflow tract formation. Am J Hum Genet 96:235-244. doi:10.1016/j.ajhg.2014.12.025

Ronowicz A, Brzeskwiniewicz M, Madanecki P, Buckley PG, Orlowska E, Ochocka RJ, Limon J, Piotrowski A (2012) Regeneration of comparative genomic hybridization oligonucleotide microarrays with dimethylurea. Anal Biochem 426:91-93. doi:10.1016/j.ab.2012.04.013

Rump P, de Leeuw N, van Essen AJ, Verschuuren-Bemelmans CC, Veenstra-Knol HE, Swinkels MEM, Oostdijk W, Ruivenkamp C, Reardon W, de Munnik S, Ruiter M, Frumkin A, Lev D, Evers C, Sikkema-Raddatz B, Dijkhuizen T, van Ravenswaaij CM (2014) Central 22q11.2 deletions. Am J Med Genet A 164:2707-2723. doi:10.1002/ajmg.a.36711

Schneider M, Debbané M, Bassett AS, Chow EWC, Fung WLA, van den Bree MBM, Owen M, Murphy KC, Niarchou M, Kates WR, Antshel KM, Fremont W, McDonald-McGinn DM, Gur RE,
Zackai EH, Vorstman J, Duijff SN, Klaassen PWJ, Swillen A, Gothelf D, Green T, Weizman A, Van Amelsvoort T, Evers L, Boot E, Shashi V, Hooper SR, Bearden CE, Jalbrzikowski M, Armando M, Vicari S, Murphy DG, Ousley O, Campbell LE, Simon TJ, Eliez S (2014) Psychiatric disorders from childhood to adulthood in 22q11.2 deletion syndrome: results from the international consortium on brain and behavior in 22q11.2 deletion syndrome. Am J Psychiatry 171:627-639. doi:10.1176/appi. ajp.2013.13070864

Schwinger E, Devriendt K, Rauch A, Philip N (2010) Clinical utility gene card for: DiGeorge syndrome, velocardiofacial syndrome, Shprintzen syndrome, chromosome 22q11.2 deletion syndrome (22q11.2, TBX1). Eur J Hum Genet 18:1-3. doi:10.1038 /ejhg.2010.5

Smigiel R, Piotrowicz M, Makowska I, Blonska A, Hoffmann K, Jakubowski L, Blin N, Sasiadek MM (2007) New bacterial artifical chromosome and commercial FISH probes for the 22q11.2 region in patients with congenital heart defect and with phenotype resembling DiGeorge and velocardiofacial syndromes. Adv Clin Exp Med 16: $717-723$

Tobias ES, Morrison N, Whiteford ML, Tolmie JL (1999) Towards earlier diagnosis of $22 \mathrm{q} 11$ deletions. Arch Dis Child 81:513-514. doi:10.1136/adc.81.6.513

van El CG, Cornel MC, Borry P, Hastings RJ, Fellmann F, Hodgson SV, Howard HC, Cambon-Thomsen A, Knoppers BM, MeijersHeijboer H (2013) Whole-genome sequencing in health care. Recommendations of the European Society of Human Genetics. Eur J Hum Genet 21:580-584. doi: 10.1038/ejhg.2013.46

Vermeesch JR, Brady PD, Sanlaville D, Kok K, Hastings RJ (2012) Genome-wide arrays: quality criteria and platforms to be used in routine diagnostics. Hum Mutat 33:906-915. doi:10.1002 /humu.22076

Wozniak A, Wolnik-Brzozowska D, Wisniewska M, Glazar R, MaternaKiryluk A, Moszura T, Badura-Stronka M, Skolozdrzy J, Krawczynski MR, Zeyland J, Bobkowski W, Slomski R, LatosBielenska A, Siwinska A (2010) Frequency of 22q11.2 microdeletion in children with congenital heart defects in western poland. BMC Pediatr 10:88. doi:10.1186/1471-2431-10-88

Yagi H, Furutani Y, Hamada H, Sasaki T, Asakawa S, Minoshima S, Ichida F, Joo K, Kimura M, Imamura S, Kamatani N, Momma K, Takao A, Nakazawa M, Shimizu N, Matsuoka R (2003) Role of TBX1 in human del22q11.2 syndrome. Lancet 362:1366-1373. doi:10.1016/S0140-6736(03)14632-6 